\title{
Breve nota dos coordenadores
}

Congeminámos este livro com base na necessidade de pensar os atuais desafios comunicativos da Política. A digitalização do quotidiano propõe uma nova relação com os atores sociais. $A$ equação a três incógnitas que configura o jogo da opinião pública está a ser redesenhada através de: meios de comunicação, políticos e cidadania que modelam o seu exercício dialético com outras estratégias, usando novas ferramentas, tecendo relações em outros moldes e gerando novas experiências. Para uma problemática carregada de nuances e possibilidades, solicitámos mão-de-obra coletiva, uma empreitada que em conjunto clarificasse um sentido para outras dúvidas.

Este livro somente foi possível graças ao empenho de um conjunto alargado de pessoas a quem queremos agradecer: a todos os autores por terem aceitado o desafio; ao Miguel Pereira, Raquel Cabeças e Madalena Mira, pela laboriosa tarefa de revisão e edição; ao Bruno Filipe pela capa; à Direção do Departamento de Ciências da Comunicação pelo incentivo e à Cooperativa de Ensino Universitário (C.E.U.) por possibilitar esta publicação. Um bem-haja a todos.

Bruno Carriço Reis (Autónoma de Lisboa - Portugal) Sergio Rivera Magos (Autónoma de Querétaro - México)

Lisboa e Querétaro, Setembro de 2019 https://doi.org/10.26619/978-989-8191-99-1.01 http://hdl.handle.net/11144/4369 